\title{
THE WHITE-FLOWERED FORM OF NODDING THISTLE IN SASKATCHEWAN
}

V. L. HARMS, Fraser Herbarium, Department of Plant Ecology. University of Saskatchewan, Saskatoon and J. B. GOLLOP, Prairie Migratory Bird Research Centre, Canadian Wildlife Service, Saskatoon, Saskatchewan

The nodding thistle Carduus nutans $L$. is one of Saskatchewan's largest and most striking weed species. The robust branching plants often reach over two metres in height and have deeply lobed prickly leaves, and large, showy, nodding, purple heads, borne solitary at the ends of long branches. This Eurasian species is widely naturalized in North America, occurring mostly in pastures, old fields, waste places, and along roadsides. While individual colonies of the species may be quite large and locally even represent obnoxious weeds, the overall occurrence of nodding thistles in Saskatchewan seems rather sporadic. We are aware of fewer than 20 localities where this species has been recorded in the province, although it probably occurs in many more places and likely is still actively spreading here.

Elsewhere throughout its range, occasional plants with white-flowered rather than purple heads are known to occur. However, to our knowledge, no white-flowered plants have previously been recorded for Saskatchewan, nor have we personally seen any. On July 26, 1975, Bernie Gollop encountered about 15 white-flowered plants among a relatively large population of typical purple-headed nodding thistles growing in a dry grazed pasture 7 miles south and 2 miles west of Dundurn, Saskatchewan. The white-flowered heads formed a striking contrast with the purple-headed ones, but both forms were exceptionally showy. Voucher collections of these plants

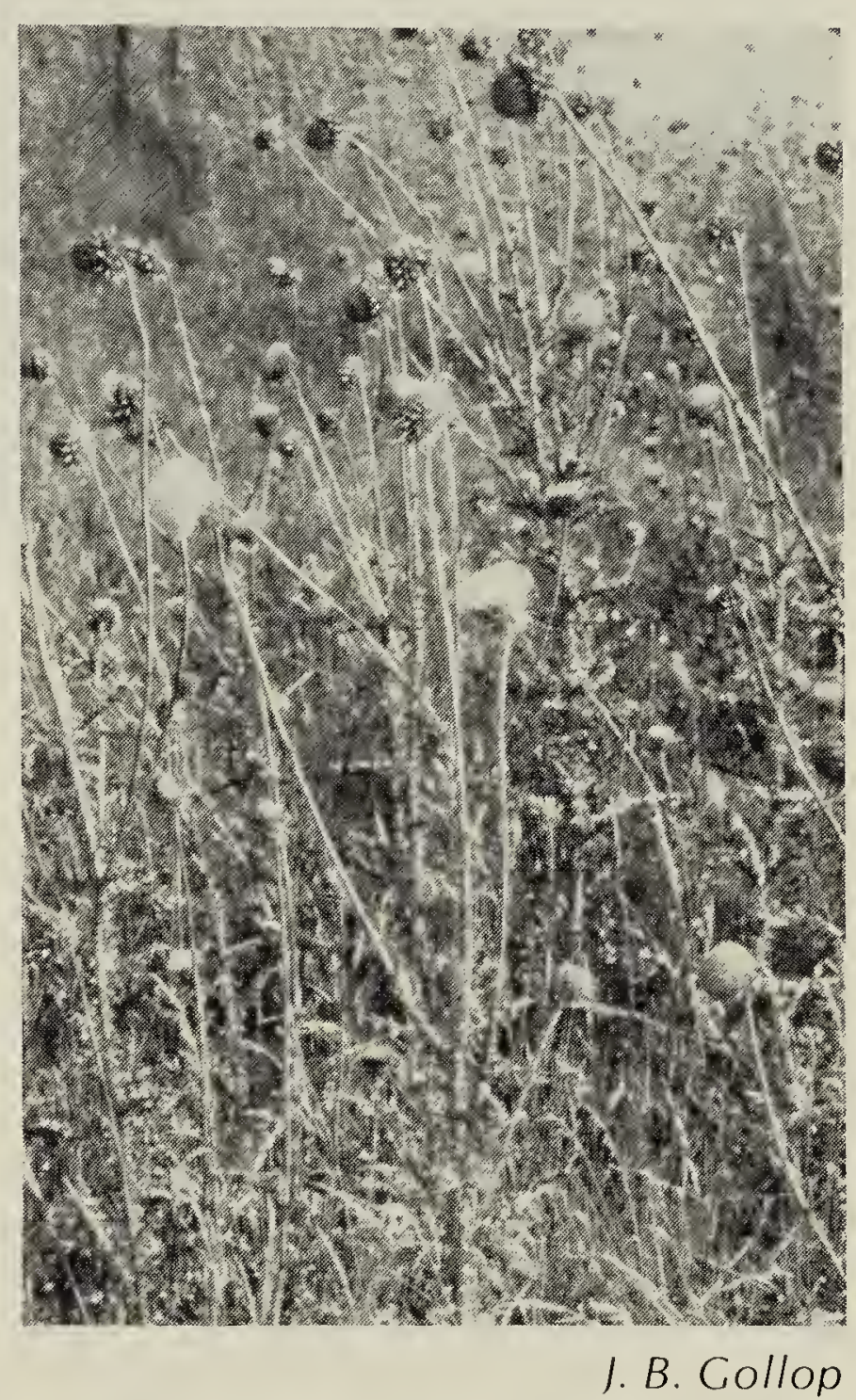

Intermixed colony of White- and Purple-headed Nodding Thistles

have been deposited in the Fraser Herbarium, University of Saskatchewan. White flowers were present and more numerous on the same site in 1977 and 1978.

We would be interested in hearing about any other Saskatchewan locality records of the white-flowered form of the nodding thistle. Perhaps it is not as rare as we have thought it to be in this province. 